\title{
Gender Sensitive Practices as Effective Tools for Implementing the Equality Policy: The Experience of Ukrainian Universities
}

\author{
Iuliana Domina
}

Assistant, Research Support Office, Stockholm University, Sweden

Yulia Savelieva

$\mathrm{PhD}$, leading specialist, Family Support Center, Sumy State University, Ukraine

\section{Nina Svitailo}

$\mathrm{PhD}$, Assosiate Professor, Head of the Department of Psychology, Political Science and Socio-Cultural Technologies, Sumy State University, Ukraine

\begin{abstract}
The article is based on the experience of creating a gender sensitive environment at Sumy State University in order to integrate the gender aspect into policies, programmes and projects related to learning activities and research, as well as other areas of the university's life. This experience is analyzed on the example of the implementation of the "Family friendly university" initiative and the practice of conducting a partial gender audit of the university's activities. The relevance of this direction is determined by the fact that, despite the existence of legislative bases and state programmes on gender equality, there is a lack of initiatives in Ukraine, which really contribute to it. There is a lack of practical tools that would help identify weaknesses in achieving gender equality and could also be used to make a real positive move towards overcoming this gender gap. As an effective tool for introducing a gender sensitive environment, we also consider gender audit, which is both a tool and a process based on participatory methodology and aimed at organizing training on gender sensitivity, both at the individual level and at the level of the structural units and administration of the university. We are confident that the procedures of gender audit allow to bring the whole complex of the organizational and communication mechanisms inside the university to the new level of efficiency and significantly expand the circle of people who are conscious and interested in being involved in the promotion of gender approaches. Gender audit can be considered as a truly universal and effective means of promoting the gender equality policy, as it allows for a complex implementation of a number of important tasks: monitoring, evaluation, communication, implementation of gender sensitive work methods, education, etc. In the future, it is expected that, through the acquaired experience, knowledge and successful gender audit practices, the HEIs will increase their efforts to create equal opportunities. As an achievement, it will be possible to assess the dissemination of the "Family friendly university" initiative as an opportunity to combine study/work in a high school with family responsibilities. It is this model that serves as a marker of gender-sensitive policies, social protection and targeting of services for vulnerable groups - students-mothers with young children and other members of the team having family responsibilities.
\end{abstract}

Keywords: gender sensitive practices, gender audit, equality policy, initiative.

JEL Classification: M42, D63.

(C) The Authors, 2018. This article is published with open access at Sumy State University.

\section{Introduction and literature review}

Speaking of the lack of initiatives and practical tools that would help identify weaknesses in achieving gender equality and promote equality between women and men in various areas of public life, we rely primarily on existing assessments in this area.

Thus, the annual global study of the world in terms of equality of genders according to the World Economic Forum (The Global Gender Gap Report, 2017), which defines a gender gap index based on measurements in four key areas (Economic participation and career opportunities; Education; Health and survival; Political rights and opportunities), gives Ukraine 61st position out of 144 countries represented in the "Gender Gap Index". This could be considered as some progress in comparison with the previous 67th position among 142 countries in 2015 and 69th position in 2016, but simultaneously - a downward movement, since in 2015 Ukraine ranked 56th. This is not a very high result and a significant gap from the top 10 countries on the gender equality index. Even the fact that in 2017, for the first time in the history of the calculation of this indicator (since 2006), the situation with gender inequality in the world has generally deteriorated, it does not save the 
situation. According to another rating - Gender Inequality Index of 2016, which reflects such aspects of human development as reproductive health, economic status and empowerment of women compared to men, Ukraine ranks 84th among 150 countries.

According to the State Statistics Service of Ukraine, the employment rate among women is lower than among men $(51.5 \%$ and $61.4 \%$, respectively, for the 1 st half-year of 2017). In 2017 , the salary of women on average was $22.5 \%$ less than of men. Thus, the average salary of men for the results of 9 months amounted to 8271 UAH, and of women - 6414 UAH (The statistical bulletin "Salary and Social-Labor Relations").

At the same time, the situation in the field of higher education and research in Ukraine is though not critical, but far from the desired and necessary, and the steps taken towards gender equality are worth of a positive assessment.

The traditional prevalence is the prevalence of women studying in higher education institutions of the III-IV accreditation levels. Thus, the share of women in the total number of persons in the 2012-2013 academic year was 52.8. At the beginning of the 2017/18 academic year the number of women among the HEIs' students in all forms of education in Ukraine was 116427 (55.8\%), including 678374 women in universities, academies, institutes, or $51.0 \%$ including among the students of full-time education -454550 people, respectively $48.7 \%$. As of January 1, 2018, 26796 persons were trained in postgraduate study programmes at universities and scientific institutions, of which 12708 were women that is $47.4 \%$; in doctoral studies -1646 , of which $898-$ women $(54.5 \%)$.

The index of gender parity among pupils and students of educational institutions of Ukraine is the ratio of the number of female participants to the number of male participants (UNESCO methodology): in the baccalaureate $-1,081$, in the master's degree $-1,243$, doctorate (or its equivalent) $-1,099$. (Statistical collection "Higher education in Ukraine", 2017).

Research conducted by the Ukrainian Center for Social Data, the purpose of which was to determine, based on open data, the trends of male and female leadership in officially registered institutions, organizations and enterprises, including in terms of industries and activities (according to the Classification of Economic Activities, 2010), shows, that in general (among legal entities and individual entrepreneurs together) education is the only branch where most managers $(69 \%)$ are women. However, in educational institutions of different levels, the proportion of women leaders decreases with the age of pupils: women are leaders in $98 \%$ of cases for preschoolers, $87 \%$ for primary, $68 \%$ for secondary education and $19 \%$ for higher education (including colleges, technical schools, universities, academies, institutes) (Women and men in leading positions in Ukraine: open data of the USREOU).

Although in this context, we should note that it is precisely in today's educational system that the most powerful research and expertise potential is concentrated, and centers are created, which even not always having a certain organizational structure, conduct active gender-sensitive education. Among the positive changes that experts link with the new leadership of the Ministry of Education and Science (for the first time a woman holds the post of minister) there is the creation and active work of the working group on gender equality and antidiscrimination issues in the field of education, as well as the Public Council (which includes a woman expert on gender issues) under the Ministry of Education and Science of Ukraine. Since the late 90's of the twentieth century gender resource centers, gender laboratories are opened at universities, and since 2012 the AllUkrainian network of gender education centers of the higher education institutions (HEIs) operates, the activity of public organizations working in the field of ensuring gender equality is being intensified. The draft of the strategy for the implementation of gender equality and non-discrimination in the field of education "Education: Gender Dimension - 2020", the draft of the road map of Ukraine's joining the European Research Area have been developed. In 2017, the first master's programme "Gender Studios" was opened at Taras Shevchenko National University of Kyiv. Each year, the All-Ukrainian contest of student research works on the topic "Gender Studies" is held; the dissertations devoted to various aspects of gender issues (in the fields of pedagogy, economics, philosophy, psychology, history, political science, literary studies, philology, sociology) are defended; regional and international scientific conferences devoted to gender issues, seminars on the improvement of the skills of teachers of higher education institutions are organized; scientific research themes (including the gender component) and gender-oriented research projects are implemented.

At the same time, the existing normative base (the Law of Ukraine "On ensuring equal rights and opportunities of women and men" (Section 5), the Law of Ukraine "On Higher Education", the Law of Ukraine "On Scientific and Scientific and Technical Activity", the Concept of the State Social Programme for Equal rights and opportunities for women and men for the period up to 2021, the draft of the strategy for the implementation of gender equality and non-discrimination in the field of education "Education: Gender Dimension - 2020", 
Final report of the independent european audit of the national research and innovation system of Ukraine (2017) (contains recommendations of the National Academy of Sciences of Ukraine on the diversification of human capital (an age and a gender balance)), the Ministry of Education and Science Order on the composition of experts, where there is an anti-discriminatory examination of textbooks of general educational institutions (including methodological recommendations for anti-discrimination expertise), the Order of the Ministry of Education and Science of Ukraine regarding the appointment of an advisor to the Minister of Education and Science of Ukraine on issues of gender equality policy and anti-discrimination in education on a voluntary basis) does not reflect the full the so-called top-level goals:

> Gender balance in all areas and at all hierarchical levels;

$>$ Elimination of structural barriers for women;

> Implementation of gender approaches in educational activities, research and training of researchers.

The appeal to the practice of introducing such approaches and initiatives into the activities of the university is due to their special mission and status in the society, which enables them to disseminate gender-sensitive approaches through researches, technology, value systems and behavioral practices to all spheres of public life. In the framework of this article, we do not set the task of a detailed analysis of the mission of a modern university and assessment of the significance of the transformations that take place. We consider this to be a subject of a separate study, especially considering the discussion of the issue and the existence of rather controversial perspectives on the university's social and educational missions, as well as its role in solving the problem of youth employment (Barnett, R., 1997), (Reedings, B., 2010), (Auzan O.), (Bakhrushin V., 2013). At the same time, it should be noted that today the activity of universities is not limited to educational and scientific activities due to the training of the personnel for all spheres of public life, active participation in the development of national, sectoral and regional programmes, the introduction of modern technologies in various spheres of life. A modern university is also an effective institute of socialization. As J. G. Newman pointed out, a student who falls into the spiritual "ecological niche" of the university develops and preserves for the whole life a desire to develop his own personality. Initially, the student follows the elders because of their authority and experience. In future, other people who surround the student (graduate) outside the walls of the university begin to follow this learned behavior (Svitailo, N., 2014). According to Newman, the personality of a student, being highly developed due to the university, inevitably becomes the locomotive of a social life. Moreover, the universities themselves are actively contributing to the formation of appropriate structures and practices, which are able to create and implement innovations oriented towards the formation and development of human capital.

Based on the understanding of the importance of universities in advancing the principles of gender equality, British scientists analyzed the situation with the perception of gender discrimination in scientific circles in the 90's of the last century (Bagilhole, B., 1993), (Farish, M., McPake, J., Powney, J. and Weiner, G., 1995). They also emphasized the importance of the concept of equal opportunities (EO) for building an organizational culture of the university (Goode, J., Bagilhole, B., 1998).

A detailed analysis of the experience of European universities in the implementation of the principles of gender equality is provided by the Ukrainian researcher I. O. Tsarenko, referring to the works of E. Geyes, J. Hugo, P. McLaren, A. Grace, P. Gutro, E. Tizdel as well as to the Athena SWAN programme. It is a national scheme designed to recognize the commitment to support and develop women's career in science, technology, engineering, mathematics and medicine (STEMM) in higher education and research. At the same time, making conclusions about the relevance of using this experience to solve the problem of gender inequality and introducing such approaches by Ukrainian higher education institutions, I. O. Tsarenko sees the following steps, first of all, in the direction of improving the educational process:

$>$ implementation in education of organizational and pedagogical conditions, theoretically proved on the basis of a gender approach;

$>$ availability of modular technology for forming the gender competence of teachers who will implement the educational process in higher educational institutions;

$>$ mastering by teachers the modular technology of forming gender competence, covering general cultural, educational, cognitive, communicative, informational and self-actualizing elements;

$>$ introduction of special gender courses in the system of higher education;

$>$ publications of specific scientific researches in the theory and methodology of gender issues, namely textbooks, manuals, collections, etc.;

$>$ development and introduction of new topics and courses on gender issues at universities. (Tsarenko, I. O., 2015). 


\section{Results and discussion}

The results of our own analysis based on the experience of the centers of gender education at 28 Ukrainian universities (Svitailo, N., 2013), really show the concentration of efforts of teachers and scientists precisely around the educational process, the educational activity, the development and implementation of new topics and courses on gender issues, etc. In addition, the peculiarity of the situation is that most tasks and problems are "presented" by specialists in an overly general form and are not perceived (and, therefore, not resolved) in the plane of individual people, students, teaching or auxiliary stuff, etc. It happens because of creation of real conditions for the self-realization and development of each individual woman and man and the specific situations of their life, in the process of work or study, in the family, in communication. At the same time our own analysis of the experience and practices of leading European and American universities (Svitailo, N., 2014) allows us to conclude that the leading universities recognize the importance to introduce gender sensitive approaches into all spheres of university life and the need to set the task much wider, going far beyond the educational process and personnel training, affecting the infrastructure elements and principles of corporate culture, establishing a system of organizational and social support for initiatives, including the establishment of a system for monitoring their effectiveness (Sagaria, 2007).

And it is precisely in this plane that we see the special role and the task of universities, which today can be centers for the formation of new approaches in the implementation of gender equality, new practices and institutional innovations, which will eventually be extended to all spheres of public life. And we see a special relevance of the research in this direction. It is determined by the lack of real practices to overcome the existing gender gap and the detachment of the majority of both professionals and ordinary teachers and students, since the current situation does not always correlate with their own lives and prospects, does not find a proper understanding and assessments in a society and is not perceived as a task that can and must be solved.

Consequently, based on the fact that the introduction of new approaches and initiatives in university life, training and education of students based on the values of gender equality is a real step towards their implementation in structural innovations, future professional activities of graduates, and hence in the social life of the country, we implemented several projects aimed at integrating gender approaches into the daily life of the university. Among them there are the "Student Stork" project, the establishment of a Family Support Center at the University, the implementation of the "Family friendly university" initiative and the implementation of the practice of conducting a gender audit of the university activity. The peculiarity of these projects (which, in fact, makes them the subject of this study), is their complexity, the close combination of scientific and research work with specific organizational steps, the development of a regulatory framework and a wide range of promotional, informational and educational activities. Thus, the implementation of the "Family friendly university" initiative, which is aimed at creating a gender-sensitive environment through the creation of supportive conditions for the development of both students and teachers in finding a balance between professional and family life, can be an example of such complexity in a combination of scientific and applied components.

It should be noted that in Ukrainian realities it is not a single fact of dissatisfaction with the impossibility of self-realization at the same time in the private and professional spheres. A substantial part of women (and men) suffer significant losses as they can not realize themselves in the professional sphere, and the state does not receive the necessary returns from the resources devoted to training specialists. The situation goes far beyond the limits of individuality and privacy, without mentioning the demographic component of the problem and the lack of conditions and attention to the younger generation. Therefore, it is logical for the university to initiate the activity to create conditions for the combination of professional and family responsibilities for the support and development of family values, for the creative and professional self-realization of persons with family responsibilities. The implementation of the "Family friendly university" initiative fully complies with the university's above-mentioned mission and certifies the responsibility of the higher education institution for students and scholars and demonstrates understanding and respect for their family responsibilities. The policy of family support at the university allows both women and men to equally realize their intellectual and creative potential and their own needs in self-realization and career.

The experience of Sumy State University in advancing gender-sensitive practices, in particular in the formation and implementation of family friendly principles, has been reflected in the creation of a unique Family Support Center. At the same time, a system of various measures aimed at overcoming gender stereotypes and ensuring the creation of equal opportunities for men and women as to the self-realization in work and education, received support from the European Commission. Within the framework of the project "Equal opportunities for obtaining a profession for young mothers-students in the HEIs", implemented by SSU with the financial 
support of the European Union, an innovative model of the "Family friendly university" initiative was developed taking into account the features and realities of the Ukrainian high school. The creation and implementation of such a model has allowed to draw attention both to the issue of gender equality and the provision of opportunities for young students for professional growth and to the problem of strengthening the social responsibility of universities, which should demonstrate to the whole society the best models to follow.

The approaches and concrete steps to implement the initiative are described in details in the manuals "Balance between education and family: opportunities for provision in higher education institutions" (Barnett, R., 1997: 54-62) and the "Family friendly university" extended initiative: experience of implementation at Sumy State University (Family friendly university). And within the framework of this article, it is important to stop first of all on the model developed by Sumy State University concerning the implementation of the initiative "Family friendly university" by adapting the structure of the university to the needs of a modern woman (a student, an academic or a non-academic employee), family and those who have family responsibilities, as well as the conditions for ensuring the long-term operation of this model in a higher education institution.

The "Family friendly university" model structure includes the introduction of a wide range of initiatives at the university level, including flexible organization of the university's educational and work processes; creation of a child friendly environment; formation of information and consulting support system; promotion of model initiatives among stakeholders and educational activities; social support of persons with family obligations; health programmes while studying / in the workplace, mass sports and health events.

The focus on system and long-term work was reflected in the functional analysis of the mechanisms for implementing the initiative through the application of the scheme: "organizational and functional support human resources - logistics and financial provision - communications - risks and mechanisms for their prevention - expected and available results". The application of such a scheme made it possible to present existing scientific developments and practical experience in the form available for dissemination and use by other HEIs. In addition, this analysis allowed not only to show the main stages and forms of work on the implementation of the initiative as an important and relevant direction for the implementation of gender approaches, but also to demonstrate its gender impartiality and neutrality, which provides truly equal opportunities for self-realization for each member of the university team and allows to take into account the peculiarities of the needs of those with family responsibilities. At the same time, special attention during the implementation of the initiative was devoted to the development of its communication structure, the establishment of constant links between stakeholders, mechanisms for the transmission of information and feedback, the removal of communication barriers, which create difficulties in perception and understanding of tasks, principles and benefits of its implementation. Such steps ensured the creation of conditions for the longterm operation of this model at the university, nd the necessary systematic efforts to promote real gender equality. It is crucial for professional growth and ensuring the access of women to decent work in future. More than six years of experience in this area shows that an effective communication structure allows to achieve maximum effect in the conditions of the currently limited material, technical and financial resources of most Ukrainian universities and the psychological unreadiness of the university leadership to take decisive and systematic steps towards the actualization of the gender perspective and the implementation of gender sensitive approaches.

It should be noted that rethinking approaches to quality education assuarance combined with increasing attention to the daily needs of students and employees (especially family ones) allowed SSU to position itself as a socially responsible institution. We consider this to be especially important, since in Ukraine today there is no sustainable tradition of social responsibility in its generally accepted meaning. Moreover, such responsibility is rarely analyzed in relation to the activities of universities. Although it a rare fact when a document or a publication devoted to the education system, is without mentioning the significance of this component of social life and the responsibility of teachers for the professional training and education of the younger generation.

As an effective tool for introducing a gender sensitive environment, we also consider gender audit, which is both a tool and a process based on participatory methodology and aimed at organizing training on gender sensitivity, both at the individual level and at the level of the structural units and administration of the university. We are confident that the procedures of gender audit allow to bring the whole complex of the above mentioned organizational and communication mechanisms inside the university to the new level of efficiency and significantly expand the circle of people who are conscious and interested in being involved in the promotion of gender approaches. 
In our case of conducting a gender audit at the university, we have followed such an understanding of this instrument as proposed by the International Labor Organization, namely, that it:

$>$ Considers whether internal practices and related support systems for gender mainstreaming are effective and reinforce each other;

$>$ Monitors and assesses the relative progress made in gender mainstreaming;

$>$ Establishes a baseline for the audited unit;

$>$ Identifies critical gaps and challenges;

$>$ Recommends ways of addressing them and suggests new and more effective strategies;

$>$ Documents good practices towards the achievement of gender equality (A manual for gender audit facilitators, 2012).

Today, gender audit is considered by research and expert circles as an effective means of improving socially oriented policy both at the state level and at the level of a separate institution or organization. Proceeding from the recognition of the relevance and potential effectiveness of gender audit as an instrument, the authors have conducted the work on the adaptation of the Gender audit methodology developed by the International Labor Organization to the conditions of a modern Ukrainian university. The peculiarity of such an adaptation was, first of all, the need to adhere to the principles of gender audit as a social one and to develop tools that can take into account the range and specificity of the activities of the HEIs.

The International Labor Organization (ILO) methodology being the basis for the development provides the principle of participation and involvement (the so-called participatory audit) and characterizes the gender audit as a new way, a monitoring tool in the promotion of gender equality policy. With the help of gender audit, one can analyze the extent to which the gender equality principles are implemented in the organization (company, university), how the gender component is integrated into strategic, programme documents, reports on the activities and functioning of the organization, and the relationship in the team (A manual for gender audit facilitators, 2012).

The feature of the gender audit documented in the ILO methodology is in the application of a self-assessment methodology, a democratic engagement, when all interested representatives of the team voluntarily have the opportunity to speak on issues related to gender, etc. Consequently, the basic principles of the methodology are the mandatory inclusion of team members in conducting an audit; a compulsory education, a raising awareness of staff through a system of seminars, schools and trainings; the use of gender-sensitive tools and gender-sensitive methods in forming groups and in procedures. Such a methodology is acceptable and desirable for higher education institutions, since:

$>$ involvement of members of the team prior to conducting an audit is an additional positive factor that allows active implementation of a gender approach;

$>$ it fully corresponds to the basic principles of the university's activities, expanding the possibilities of scientific and educational work;

$>$ it is able to stimulate the process of self-education at the level of the university in general, separate units and each individual member of the student team or teaching staff.

At the same time, the complexity of the practical implementation of these basic principles not only allowed to come to important conclusions about the need to take into account the peculiarities of the educational environment, but also stimulated the development of appropriate tools. Difficulties arose both at the level of organization of such a large-scale work, and at the level of insufficient workability of the methodology, indicators, complexity of the results analysis, in particular of qualitative indicators. In addition, it was problematic to conduct a gender audit that would cover all areas of the HEIs' activity, given the complexity of the tasks and the lack of sufficient resources at the present time, even at a powerful university (taking into account the specificity of a gender audit as a social and participatory one). We are talking about a lack of experts and motivated staff within the university for a quality audit.

The ILO methodology provides involving to the audit the largest possible number of participants from among the members of the team who would be trained, begin to observe gender imbalances and analyze their causes. Therefore, the main requirement is the formation of groups of performers to be audited directly in the units. In addition, while forming working groups and identifying those responsible for directions, it is desirable to maintain a gender balance, including both men and women into groups. Participation practice, which is a key feature of a gender audit (Moser, C., 2005: 4), (Swirski, B., 2014) is to take into account not only the organizational structure and culture of the university as a whole as well as individual units, to develop and 
implement the gender sensitive programmes and projects, but also the ability to track system processes and opportunities for participation in these processes of both men and women (Moser, C., 2005: 4), (Swirski, B., 2014).

Equally challenging was the development of tools aimed at obtaining objective information, raising the level of gender knowledge and forming a gender-sensitive environment. Especially considering the requirements of the ILO methodology, which focuses on the participativity of such an audit and the targeting of tools not only for monitoring and collecting information, but first of all for increasing the level of gender knowledge and communication within the team. Moreover, the relevance of the developed toolkit to the specifics of the particular areas of the university or individual faculty included in the audit programme, as well as the potential effectiveness of the toolkit, taking into account the characteristics of different target groups, in particular, students, is also important. Proceeding from the above, a package of tools was created (questionnaires, guides of focus group research, plans-recommendations for document analysis, including normative documents, tables, topics of seminars, trainings of discussions, forms for preparation of reports, etc.) that met the following requirements:

$>$ constant concentration on the need to take into account the characteristics and needs of both men and women, the departure from the analysis of the gender issue exclusively as "female";

$>$ taking into account the features of different target groups (students, teachers, employees) in order to cosider their interests;

$>$ obtaining objective information on the current situation with ensuring gender equality in selected structural units;

$>$ familiarizing with the gender issue of the widest possible range of teachers, staff and students, and identifying ways to effectively implement the gender component in curricula and research;

$>$ promoting gender culture and overcoming stereotypes.

Special attention during the preparatory work and briefings was drawn to the search and development of indicators capable of correctly reflecting the current situation (Gender Indicators, 2007). They included: incorporating gender perspectives into strategic plans and other software documents; the language of documents and manuals, which is correct in terms of gender equality; the presence and status of a center or other unit, a contact point on gender equality; the presence of other units or groups (e.g. trade unions) that support and monitor gender-specific activities; the introduction of gender aspects as separate disciplines or topics in curricula of specialties; the presence of female images in media (e.g. photos on websites, in publications, etc.); the level of personnal awareness on gender issues; the peculiarities of assessing the gender equality by men and women; the share of men and women in the staffing, including in managerial positions; the existence of structures and supporting conditions for persons with family responsibilities; the availability of accepted and valid normative documents and guidelines in the field of positive discrimination; the increase in the number of male executives who publicly advocate for gender equality and women's legitimate rights; the inclusion of courses on the elimination of legal literacy, on human rights and gender equality in programmes of postgraduate education and skills upgrading.

Since at the time of implementing the first steps in the development of tools in Ukraine there was no experience in carrying out a gender audit at the universities and even the practice of conducting the full audits at enterprises and other organizations, the resources that we could use were the developments and experience of foreign scholars and the collective work of the All-Ukrainian network of gender education centers, supported by the Friedrich Ebert Foundation in Ukraine. The first findings and tools developments were tested in the framework of gender audit at the Faculty of Foreign Philology and Social Communications of Sumy State University. They were discussed and supplemented during the joint seminars of the All-Ukrainian network of gender education centers at universities. Here the authors presented an adapted method of gender audit of the university's activities. The training of experts on approaches to gender audit and meetings on adaptation of the methodology to the conditions of Ukrainian universities and the development of tools were organized in partnership with the Representative Office of the Friedrich Ebert Foundation in Ukraine. These events made it possible to get acquainted with the best foreign experience. After that, almost all submitted tools were used during the conduct of partial gender audits at 15 Ukrainian universities in 2015. Conducting pilot gender audits within the project of Sumy State University "Gender mainstreaming in higher educational institutions of Ukraine" was supported by the Foundation of Local Initiatives of the Embassy of Finland in Ukraine (Family friendly university).

The participants of the pilot project were: Vinnytsia National Technical University, Oleksandr Dovzhenko Hlukhiv National Pedagogical University, Zaporizhzhya National University, Taras Shevchenko National University of Kyiv, Lutsk National Technical University, Lutsk Pedagogical College, National Mining 
University, National Technical University "Kharkiv Polytechnic Institute", Lviv Polytechnic National University, The National University of Ostroh Academy, Sumy State University, Ternopil Volodymyr Hnatyuk National Pedagogical University, Khmelnytskyi Humanitarian-Pedagogical Academy, H.S. Skovoroda Kharkiv National Pedagogical University, Kharkiv National University of Radio Electronics.

As the authors of the manual "The Gender Audit Handbook. A Tool for Organizational Self Assessment and Transformation" point out a transformation can take place only when four organizational dimensions are ready for gender integration: "These four elements are political will, technical capacity, responsibility and organizational culture" (Gender Audit Handbook, 2010).

Agreeing with the author's team of the quoted publication, we note that these four components should be a subject to preliminary discussion and analysis, regardless of which field of the university activity will be selected for the audit. For example, this could be a scientific activity or a visual space of the university, during the analysis of which we must study and evaluate: the willingness of the university management or responsible department to see gender features and work on achieving equality; the work and qualifications of the staff that provides this activity or is part of the working groups, in terms of the ability to see gender features and work in this area; factors and mechanisms that promote gender equality and have significant expressions for the given sphere of activity and form the corresponding images and stereotypes. The responsibility is equally important - those mechanisms that determine compliance with the requirements in the context of gender equality integration into programmes and their own organizational structure as well as organizational culture - the regulatory framework, customs, beliefs and codes of conduct in organizations that support or undermine gender equality.

Speaking about the importance of such a component as a political will (the ways in which leaders, the university administration use their position or demonstrate their support, leadership, enthusiasm and commitment to work to support gender equality (Gender Audit Handbook, 2010: 23), we should note the positive general perception of the idea and procedure of gender audit by the leadership of the above-mentioned HEIs - project participants - at the level of universities in general or at the level of individual faculties. The fact that the ratio of men and women in the management of the HEIs (one of the quantitative indicators during the audit of 15 universities) can hardly be called close to parity: the number of men and women in the rectorates - respectively ( $16 \%$ and $84 \%$ ), as part of the labor collective conference ( $31 \%$ of women and $69 \%$ of men), in academic councils ( $28 \%$ of women and $72 \%$ of men), in the management of faculties and institutes $(27 \%$ of women), in the management of trade union organizations $-42 \%$ ).

Based on the experience of Sumy State University, which was the initiator of the project and the first to participate in the gender audit procedure, we can outline the main steps (algorithm) for conducting the gender audit (GA).

1. Definition of areas or separate structural units that will be subject to audit. The criterion for making such a decision will be, first of all, the own will and readiness of the team. At SSU we have chosen staffing issues, academic activities and a system of services focused on a combination of work / study with family obligations.

2. Determination of the involved structures (dean's offices, a personnel department, a research department, a library, a trade union committee, a student's rectorate, a Family Support Center, a Gender Resource Center). The initiative came from the Gender Center (GC), as well as initial methodological and organizational support.

3. Formalization of the "political will", the coordination of key issues with the leadership of the university and the creation of the initiative group (with a gender balance). Sumy State University had and has a "favorable" feature - the presence of an actively working GC and the coordination of this direction by the Coordination Center for Humanitarian Policy (the status of the vice rector). All the specified tasks, terms, estimates and the list of involved structures (the right to form working groups according to the directions) were determined by a special order of the university, which was accompanied by a general plan and a toolkit version.

4. Organizing the working meetings in the units for the purpose of forming working groups at the faculties and according to directions through by forces of the Gender Center and the Family Support Center. The task of such meetings was to familiarize future auditors with general approaches, to form initial positive motivation, as well as to discuss the tools and principles of working with him. At the same time, the most difficult task was to achieve the participation parity of men.

5. Conducting exercises for working groups as well as a series of seminars and trainings at all faculties based on the previously developed materials for the All-Ukrainian network of gender education centers. For 
example, at SSU with the support of the trade union committee and student's rectorate, more than 700 persons participated in seminars and trainings at all faculties, including the staff of administrative and economic services, libraries and accounting offices.

Such an algorithm was implemented during the GA in the framework of the project "Gender Mainstreaming in Higher Educational Institutions of Ukraine". At the same time, no full-scale audit was carried out in any of the HEIs - project participants. Even at the start of the project, it was determined that it would be more appropriate to conduct a partial gender audit, that is, one that will focus on one or more areas of the HEI activity. After all, a modern university is a branched complex that should provide not only direct educational and scientific activities, but also other necessary components (educational buildings, scientific laboratories, public catering complexes, structures providing financial and economic, publishing, informational and advertising activities, social issues and dormitories economic services, etc.). But even a powerful university, while having no experience and methods, can not conduct a full gender audit today. Therefore, within the framework of the pilot project spheres of analysis were a personnel situation, a scientific activity and a level of knowledge of the staff on gender issues.

In general, GA results were positive. The gender audit was carried out with the wide participation of labor collectives and students of the involved educational institutions. More than 350 persons-executors were included in working groups of the units that were audited in 15 HEIs. Although not all the universities have been able to sustain the claim for the gender balance of such groups (especially in pedagogical HEIs, where the percentage of men involved was less than $10 \%$ ).

Positive results of the audit include the overcoming of the most widespread stereotype of considering the dean's office or the center of gender education as the sole performer while conducting the audit. This overcome in $90 \%$ of cases was due to the wide involvement of students and trade union representatives. The personnel of specialized chairs and gender centers acted as responsible persons, experts, consultants. Thus, one of the basic principles of the ILO methodology has been maintained. It provides involvement to the audit of as many participants as possible, who would study, begin to notice gender imbalances, analyze their causes and seek ways to overcome them. The positive result that can provide the necessary level of responsibility and the further implementation of the results obtained in practice can be considered to be joining the working groups in almost all HEIs by the management of the structural divisions - deans and their deputies, heads of the chairs, heads of the units or departments.

For almost six months, research on gender issues, a series of educational activities, a study of the human resources situation and the relevant legal and regulatory framework of the institutions have been conducted. In part, such experience is described by the individual project participants (Babenko, I., Males, L., Kharchenko, O., Chervinska, T., 2016).

More than 2,600 people took part in various seminars, discussions, round table meetings, trainings on gender issues. This result was achieved through the use of different forms of work: curriculum resources for the first year students and workshops with elements of training for academic groups; the work of activists of gender centers, departments and, in part, student curators and student self-government on a peer-to-peer principle. In addition, in all the universities involved in the project, a number of additional informational and mass events were held. They are articles in the university newspaper, information clips on electronic scoreboards in buildings, interviews on university television studios and Internet radio, contests of drawings and flash mobs in buildings, gender-based sport orienteering on the basis of a university campus, book exhibitions and quizzes, student conferences and debates, etc. Thus, almost all the stuff, including auxiliary and technical workers, knew about the audit at the level of the units involved in it. It facilitated the process of questioning and analysing documents. This is also an important positive result of the GA, since we have clearly set out and brought to the fore educational, informational and communication tasks. This fact contributed to the formation of a positive atmosphere in the course of work.

In addition, the audit results were presented at all universities, which greatly expanded the audience of those who more or less became acquainted with the problem in general and the state of affairs in a particular HEI. Besides, some of the results were visualized and posted on the website of the All-Ukrainian network of gender education centers.

During the study of assessments of gender equality by teachers, students and employees and of their views on the discrimination, 5,098 people were interviewed, including 1,214 teachers and co-workers and 3,884 students. The survey was conducted according to the proportional sample. 
The results of the survey showed that the issue of ensuring equal opportunities for men and women is defined as an important by $47 \%$ of the respondents. At the same time, it is women who indicate the importance of such equality much more often (in different HEIs this index varies from $52 \%$ to $61 \%$ ). In general, $58 \%$ of the teaching staff and $64 \%$ of students indicate that the performance of official duties does not depend on sex. But those who say that performance depends on sex, mostly have a traditional imagination of a man as a leader, and a woman as a performer. Especially it concerns the teaching staff. After all, the majority of interviewed teachers-women (about 66\%) believe that leadership in professional self-realization is independent of sex, while among their male colleagues this figure is only 37\%. Women interviewed (including teaching staff, students, staff) almost twice as often indicate overloading with family responsibilities and domestic affairs of women $(43.6 \%)$ than men $(22 \%)$. About $38 \%$ of respondents agree with the greater effectiveness of the male leader, concerning that a woman does not have enough time due to family responsibilities.

Representatives of students are more likely to notice differences in attitude towards themselves or others by gender from the teaching and support staff of the university: in general, about $46 \%$ of male and female students in contrast to $26 \%$ of female and male teachers. At the same time among the students, the male half was more gender-sensitive. The main differences noted by students and teaching are the condescending attitude towards women / girls (26\%), obstacles to women's career advancement (23\% of respondents), sexism (25\%), involvement of boys in physical labor (18\%). At the same time, in assessments of students of pedagogical HEIs, the contingent of which is predominantly female, there are frequent complaints of this part of the respondents for such condescension of teachers in relation to a small number of male students.

As this was the first pilot experience in conducting the GA of the universities' activities, its official results were not drawn up in a separate official report within the framework of the project. The main attention was paid to the results' coverage and discussion directly in the teams - during the roundtables, academic councils, conferences, on websites of faculties and gender centers. At the national level, these results were presented at the final conference of the project "Gender Mainstreaming in Higher Educational Institutions of Ukraine", on the website of the All-Ukrainian network of gender education centers (e.g. http://gendercenter.sumdu.edu.ua/) and on the site of SSU as the project implementer (e.g. http://leleka.sumdu.edu.ua/uk/news/532-gendernijmejnstriming-u-vishchikh-navchalnikh-zakladakh-ukrajini.html).

\section{Conclusions}

The concrete results of the GA are: a significant increase in the interest in the gender issue, which is expressed in increasing the number of appeals from the structural units to the gender centers and resource centers in getting a consultation and asking for seminars and trainings on the gender issue. On the example of Sumy State University, we can talk about some improvement in the personnel balance (although it is difficult to say if this was only the result of GA); a higher percentage of gender-sensitive and gender-neutral language in the documentation and on official sites; an adoption of several amendments to the Collective Agreement; an improving the socio-psychological climate and the authority of the GC.

Among the positive points, we can also mention the fact that the implementation of the project "Gender Mainstreaming in Higher Educational Institutions of Ukraine" was positively perceived by the administrations of universities and colleges, since it allowed to combine efforts and explore the possibilities of such a practical tool as the gender audit appears to be for the development and implementation of innovative, gender-sensitive technologies in the practice of higher education, the formation of the students' gender culture.

As a result of this activity, recommendations were made for the administration of the institutions concerning the integration of the gender approach into the educational and work process. Thus, by spreading the practice of gender audit in 10 regions of Ukraine, it was possible to draw attention to the issue of gender equality at the universities and to increase the motivation of the university administration to implement a policy of equal rights and opportunities for women and men. Additionally, through the exchange of experience, information, knowledge and practices, the best educational experience, the possibilities of disseminating the model and practices developed at SSU of family-friendly approaches. They serve as markers of gender-sensitive policies, social protection and services in relation to the vulnerable groups - students-mothers with young children and other members of the team having family responsibilities.

Thus, gender audit can be considered as a truly universal and effective means of promoting the gender equality policy, as it allows for a complex implementation of a number of important tasks: monitoring, evaluation, communication, implementation of gender sensitive work methods, education, etc.

While developing the project, we saw it as a logical step toward the global goal of promoting gender equality and implementing gender-sensitive approaches at Ukrainian universities. At the same time, we hoped that the 
spread of the practice to conduct a gender audit would draw attention to the issue of gender equality at universities and would motivate the administration to implement a policy of equal rights and opportunities for women and men, which allows each individual, regardless of gender, to fully realize themselves in the educational space. Moreover, based on the role of universities in the life of modern society, it is possible to say with certainty that the established practices and approaches will eventually become an integral part of the life of various structures and organizations where graduates will work.

In the future, it is expected that, through the acquaired experience, knowledge and successful gender audit practices, the HEIs will increase their efforts to create equal opportunities. As an achievement, it will be possible to assess the dissemination of the "Family friendly university" initiative as an opportunity to combine study / work in a high school with family responsibilities. It is this model that serves as a marker of gendersensitive policies, social protection and targeting of services for vulnerable groups - students-mothers with young children and other members of the team having family responsibilities.

\section{List of abbreviations}

HEI - higher education institution;

STEMM - science, technology, engineering, mathematics and medicine;

ILO - International Labor Organization;

GA - gender audit;

GC - Gender Center.

\section{References}

1. A manual for gender audit facilitators: The ILO participatory gender audit methodology, 2nd Edition Geneva, International Labour Office (2012). Available at: http://www.ilo.org/wcmsp5/groups/public/--dgreports/---gender/documents/publication/wcms_187411.pdf.

2. Atkinson, M., Carryer, A. (2000). Women and Governance in Higher Education, Women in Leadership and Management in Higher Education Series of Workshop Modules, Association of Commonwealth Universities / Commonwealth Secretariat, London.

3. Babenko, I., Males, L., Kharchenko, O., Chervinska, T. (2016). Na shlyakhu do hendernoyi rivnosti v osviti [On the path to gender equality in education], Visnyk of Taras Shevchenko National University of KyivSeries of Sociology - 1(7).

4. Bagilhole, B. (1993). Survivors in a Male Preserve: A Study of British Women Academics' Experiences and Perceptions of Discrimination in a UK University. Higher Education 26: 431-47. Google Scholar, Crossref.

5. Balance between study and family: opportunities of its provision in higher education institutions. Available at: http://leleka.sumdu.edu.ua/images/docs/balans_final2.pdf.

6. Bakhrushin, Volodymyr. Misiya universytetiv u sviti: istoriya ta suchasnist' [Mission of Universities in the World: History and Present]. Available at: //http://education-ua.org/ua/articles/167-misiya-universitetiv-usviti-istoriya-ta-suchasnist.

7. Barnett, R. (1997). Osmysleniye universiteta (Po materialam inauguratsionnoy professorskoy lektsii, prochitannoy v Institute obrazovaniya Londonskogo universiteta 25 oktyabrya 1997 goda) [Comprehension of the University (Based on the materials of an inaugural professor's lecture given in the Institute of Education, University of London, October 25, 1997)]. Available at: http://charko.narod.ru/tekst/alm1/barnet.htm.

8. Bond, S. (2000). Women in Leadership, Women in Leadership and Management in Higher Education Series of Workshop Modules, Association of Commonwealth Universities / Commonwealth Secretariat, London.

9. Family friendly university. Official site. Available at: http://leleka.sumdu.edu.ua/uk.

10.Farish, M., McPake, J., Powney, J. and Weiner, G. (1995). Equal Opportunities in Colleges and Universities: Towards Better Practices Oxford: SRHE and OUP. Google Scholar.

11.Gender Audit Handbook (2010). Available at: https://www.interaction.org/sites/default/files/Gender\%20 udit\%20Handbook\%202010\%20Copy.pdf.

12.Gender Indicators: What, Why and How? Prepared by Justina Demetriades and based on BRIDGE's Gender and Indicators Cutting Edge Pack (2007). Available at: http://www.bridge.ids.ac.uk/ reports_gend_CEP.html\#Indicators, http://www.oecd. org/dac/gender-development/43041409.pdf.

13.Genovate's Gender Equality Actions for University College Cork, Ireland. Available at: https://www.ucc.ie/en/media/research/iss21/GEAP.Infographic..pdf. 
14.Gold, A. (2004). Developing Management Skills, Women in Leadership and Management in Higher Education Series of Workshop Modules, Association of Commonwealth Universities / Commonwealth Secretariat, London.

15.Goode, Jackie, Bagilhole, Barbara (1998). The social construction of gendered equal opportunities in UK universities: a case study of women technicians. First Published May 1, 1998.

16.Gosteva, Natalia (2009). Hendernyy audyt//Pratsya i Zakon [Gender audit // Labor and Law], 10(118), 2425. Available at: http://employers.org.ua//assets/files/Social_aspects/Gosteva.pdf.

17.IFI Gender Audit and Advocacy. A Toolkit for Chinese Civil Society Organizations. Available at: http://www.genderaction.org/images/ Gender\%20Action-ChinaToolkitweb.pdf.

18.Kohut, I. (2014). Chym vidriznyayut'sya zhinky i choloviky: pro hendernu (ne)rivnist' u vyshchiy osviti [What distinguishes women and men: about gender (non)equality in higher education]. Available at: http://www.cedos.org.ua/uk/discrimination/chym-vidrizniaiutsia-zhinky-icholoviky-pro-hendernu-nerivnist-u-vyshchii-osviti.

19. Martsenyuk, T. Henderna rivnist' u vyshchiy osviti Nimechchyny: yak vtilyuyut' polityku rivnykh prav i mozhlyvostey [Gender equality in higher education in Germany: how to implement a policy of equal rights and opportunities]. Available at: http://povaha.org.ua/henderna-rivnist-u-vyschij-osviti-nimechchyny-yakvtilyuyut-polityku-rivnyh-prav-i-mozhlyvostej/.

20.Moser, C. (2005). An Introduction to Gender Audit Methodology: Its design and implementation in DFID Malawi. Overseas Development Institute Available http://www.ndr.mw:8080/xmlui/handle/123456789/1130.

21.Newman J. G. The idea of the university. Available at: http://www.charko.narod.ru/tekst/Newman/Newman.html.

22.Official site of the State Statistics Committee of Ukraine. Available at: http://ukrstat.gov.ua.

23.Reedings, B. (2010). University in ruins / Monograph. - M.: Publishing house of State University, Higher School of Economics, 304 p.

24.Sagaria, M. Women, Universities and Change: Gender Equality in the European Union and USA. Available at: https://books.google.com.ua/books?id=oGuADAAAQBAJ\&pg=PA27\&lpg=PA27\&dq=university+gende r+audit\&source=bl\&ots=ygC_YTSiSH\&sig=QhSnnEHXXviValWFqqaXLsyFwAM\&hl=ru\&sa=X\&ved

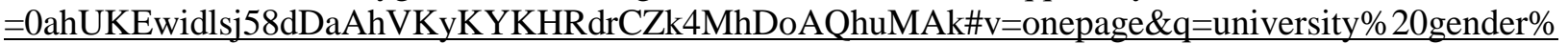
20audit\&f=false.

25.Sheffield Hallam University. What is Athena SWAN. Available at: http://www.shu.ac.uk/university/overview/diversity/athena-swan.

26.Statistical collection "Higher education in Ukraine" (2017). Available at: http://www.ukrstat.gov.ua/.

27.Svitailo, N. (2014). Expanded Initiative "Family friendly university": Experience of implementation at Sumy State University: Textbook. - Sumy: RA Publishing House "Khoroshye lyudy", 104 p.

28.Svitailo, N., Savelieva, Yu., Davlikanova, O. (2016). Hendernyy audyt diyal'nosti vyshchykh navchal'nykh zakladiv [Gender audit of the higher education institutions activity]. Practical handbook. Available at: http://library.fes.de/pdf-files/bueros/ukraine/12877-20161027.pdf $\quad$ http://library.fes.de/pdffiles/bueros/ukraine/12877-20161027.pdf.

29.Svitailo, N. (2013). Formation of gender-responsive behavior in youth by example of Ukrainian universities): Textbook. - Sumy: RA Publishing House "Khoroshye lyudy", 209 p.

30.Swirski, B. (2014). What is a Gender Audit? Available at: https://adva.org/wpcontent/uploads/2014/09/What-20is-20a-20Gender-20Audit.pdf.

31.The Global Gender Gap Report (2017). Available at: http://reports.weforum.org/global-gender-gap-report2017/dataexplorer/\#economy=UKR.

32.The statistical bulletin "Salary and Social-Labor Relations". Available at: http://www.ukrstat.gov.ua/.

33.Tsarenko, I. O. (2015). Reference a Journal Article: Henderna polityka u sferi vyshchoyi osvity: problemy nerivnosti ta shlyakhy yikh vyrishennya [Gender policy in higher education: the problems of inequality and the ways of their solution] // Economics: realities of time. Scientific Journal, 3(19), 110-117. Available at: http://economics.opu.ua/files/archive/2015/n3.

34.West, M. S. and Curtis, J. W. (2006). AUP Faculty Gender Equity Indicators, American Association of University Professors (AAUP). Available at: http://www.aaup.org/NR/rdonlyres/63396944-44BE-4ABA9815- 5792D93856F1/0/AAUPGenderEquityIndicators2006.pdf (accessed 10th January 2012).

35.Wickramasinghe, M. Training module Introduction to Gender Mainstreaming Universities Prepared for the Association of Commonwealth Universities. Available at: https://www.acu.ac.uk/focus-areas/genderprogramme/intro-gender-mainstreaming-universities.

36.Women and men in leading positions in Ukraine: open data of the USREOU. Available at: http://socialdata.org.ua/edrpou-gender/. 